GIS - 理論と応用

Theory and Applications of GIS, 2013, Vol.21, No.1, pp.1-7

【研究・技術ノート】

地理空間情報の時空間化の検討とつくば市における試作

小荒井衛 $*$ ・ 中埜貴元 $* *$

\title{
Trial Production of Temporal Geospatial Dataset about Tsukuba City
}

Mamoru Koarai, Takayuki Nakano

\begin{abstract}
We considered the specification of temporal geospatial information, and produced a temporal geospatial dataset of the area close to Kenkyu-Gakuen Station of the Tsukuba Express in Tsukuba City. Using geospatial data of each year generated from the temporal geospatial dataset, we conducted a temporal spatial analysis of human impacts such as the development of a new traffic network and land surface change such as land use. Effective temporal spatial analysis is possible using a temporal geospatial dataset if the dataset is revised with high temporal resolution.
\end{abstract}

Keywords: 時空間データセット（temporal geospatial dataset）, 時空間解析 (temporal spatial analysis)，つくば市 (Tsukuba City)

\section{1. はじめに}

地理空間情報を国土計画や環境分野等の様々な分 野で高度利活用していくためには，地理空間情報に 時間軸を加えることで地物の高頻度な変化を容易に 管理し，これまで取得されてきた過去の地理空間情 報も含めて貴重な財産として付加価值を持たせるこ とが不可欠である.

これまでの中縮尺の地形図の作成は，ある時間断 面の国土表層部の実態を全面的に作成するという手 法で行われてきた。しかし, 昨今では地理空間情報 の時間的鮮度に対するニーズが高まっており，鉄道 や主要な道路等が開通すると即時に修正して刊行す るなど，準リアルタイムな更新が行われるように なってきている。ただし，鉄道・道路のような地物 は適宜更新されても, 土地利用・等高線などの情報 は全面的な修正時にしか更新されないことが多く， 地物種類毎に更新頻度が異なるのが実態である。そ こで，地理空間情報のデー夕管理は図面単位で行う のではなく, オブジェクト指向の考え方に基づいて, 地物毎に発生・変化·消滅等の時間情報を加えてデー 夕を作成し，一元化されたデータセットとして地物 単位で管理する方が有効かつ効率的である。このよ
うな地物単位でのデー夕管理はデー夕管理者の業務 を効率化し，また，一元化されたデータセットから 特定の時点（日付）の地理空間情報を抽出すること で, 様々な時点の最適な状況の地理空間情報を出力 することができる。

一方, 地形図のような基本図は特定の部署で作成 されるが，それに含まれる情報（項目）と同等の地 理空間情報が，土地利用図のような主題図や航空 レーザによる DEM，測地基準点情報として，基本 図とは独立して整備されてきている。 これらの基本 図内の情報と重複する情報を，位置・時間・属性情 報も含めて個別に維持管理し，それらの情報を1つ のデータセットとして一元的に組み合わせること で，共通白地図としての基本図を効率的に作成する ことが可能である。すなわち, 各地物を専門的に維 持管理する部署毎の体制に応じた最良のスペックで データの管理・更新を行うことができ，それを基本 図に反映することで，最適な位置精度情報と時間精 度を持った基本図データの作成が実現可能となる.

このような背景のもと，筆者らは国土表層部の実 態を表す中縮尺の基本図を対象に，一元のシステム 化された時空間情報として管理できる仕様を検討

\footnotetext{
* 正会員 国土地理院 (Geospatial Information Authority of Japan)

T 305-0811 茨城県つくば市北郷 1 番Ｅ-mail: koarai@gsi.go.jp

** 非会員 国土地理院 (Geospatial Information Authority of Japan)
} 
し，そのようなデー夕の高度利活用可能性を検討し たので，その結果を報告する。

\section{2. 地物の時間情報の持たせ方の検討}

時間データベースの研究は 1980 年代末から行わ れており，登録時間と実在時間を併用したデー夕 ベースの提案 (Kumar et al., 1989) や歴史データベー スの検索言語の開発 (Snodgrass, 1997) などがある. 地理情報システムにおける時間情報の取り扱いにつ いては, データ更新を扱うもの（Raafat et al., 1994） が中心であったが，1990年代からは地物の時間属 性をあつかうもの (Cameron, 1990; Worboys, 1994 な ど）が増加してきている，国内では，1990年代後半 から時空間情報管理システムとして位相暗示型の データベースが提案され（畑山ほか，1999；野中 . 大澤，2001など), カーナビゲーション用のデー夕 フォーマットとして採用されている (KIWI検討委 員会，1998）。最近の時空間データベースに関する 研究は, ITSなどの車の移動や人の移動など, より 時間変化の激しいものを対象にした研究（関本・柴 崎, 2000）に移ってきている.

地理空間情報を時空間化するにあたり，最初に地 物に付与される時間情報の種類について検討した。 今回提案する時空間 DBは, 地理空間情報の解析に も活用できるようにしたい. 国家地図作成機関の場 合, 地方自治体の業務のように申請・届出のあった 情報を DBに入力する訳では無いので，登録時間を 採用した場合にはDBに職員が入力する日付が時間 情報となる。それでは実際に発生・消滅・変化した 時間とはかけ離れてしまい, 実変化を捉える解析に 使用することは困難である。そのため, できる限り 実際の生成消滅等の時間に合うように，実在時間を 採用することにした。

次に, 地物の時間情報の持たせ方について検討し たが, 大きく2つの方法が考えられる，1つは各地 物の属性テーブルに時間情報を持たせる方法で, 本 論文ではこの手法を「時間属性手法」と呼ぶ. 門脇 ほか（2001）は, この手法で数值地図 2500 の時空間 化を試みている。 もう1つの方法は, 水平位置, 高 さ情報等の位相情報と同等の $\mathrm{n}$ 次元情報として時間 情報を持たせる方法で，本論文ではこの手法を「n 次元手法」と呼ぶ.

時間属性手法は, GISの属性テーブルに時間情報 を記入する方法であるため, 市販の GIS で対応が可 能である。一方, $\mathrm{n}$ 次元手法の場合は，時間情報を 位相情報と同次元に扱える特殊な時空間 GIS ソフト が必要となる。このような GISソフトはDiMSIS (畑 山ほか, 1999), STIMS (野中・大沢, 2001) などい くつか提案されているが，市販されている通常の GISソフトには無い。また，筆者らは作成した時空 間データセットを使った時空間解析を実施したいと 考えているが，DiMSISやSTIMS はデー夕管理を目 的としたもので, 解析機能は装備されていない。 そ こで筆者らは，今回検討する時空間データセットの 時間情報の持たせ方は時間属性手法を採用すること とした。 このデータセットを使って時空間解析を行 う場合には, 解析者が解析に必要な特定の時点の GIS データを時空間データセットから抽出して高頻 度時系列の GIS データを作成し，一般的な GIS ソフ 卜を使用して高頻度時系列解析を行うことで対応す ることにした

なお，カーナビに扔ける車線規制情報など，刻一 刻と変化する情報については，時間属性手法で時間 情報を持たせると，属性テーブルのデー夕量が膨大 になり，デー夕管理や検索等の処理に時間がかか るため現実的ではない。このような場合には，n次 元手法を採用して時空間 GIS ソフトでデー夕管理を 行った方が良いと判断される。しかし，筆者らが今 回検討対象とした地理空間情報は，国土表層部の現 状を示す地理空間情報であり，刻一刻と高頻度に状 況が変化するものではない. よって, 時間属性手法 でも十分に対応可能なデータと判断した.

\section{3. 時空間データ仕様の検討}

地理空間情報の時空間化のためのデータ仕様の検 討は，それぞれの地物項目の特性に応じて最適な仕 様を検討する必要がある。本研究では, 交通網や建 物，行政界，筆界のように，個別に発生や消滅が任 意に生じうる地物・境界 (「発生消滅型地物」とよぶ) と, 土地利用やDEMなどのように必ず一義的に存 
在し面的に覆うデータ（「被覆型地物」とよぶ）とに 別けて検討した。これまで旧版地形図を対象にした 研究 (明野ほか, 2002) や数值地図2500を対象にし た研究（門脇ほか，2001）はあったが，いずれも被 覆型のデー夕は対象にしておらず，今回の検討は新 たな試みと言える。

\section{(1) 発生消滅型地物の時空間デー夕仕様}

発生消滅型地物については, 基本的に畑山ほか （1999）で示されている考え方を踏襲し, 個別の地 物に対して発生開始 $(\mathrm{SS})$, 発生完了 $(\mathrm{SE})$, 消滅開 始 $(\mathrm{ES})$, 消滅完了 (EE) の4つの時間属性を持たせ た（図-1)，行政資料 (官報) 等で厳密な時間情報が 確認できる場合には, 時間属性について日単位まで の正確さで入力が可能である。一方, 地物が変化し た時間が航空写真や衛星画像等の画像資料でしか確 認できない場合には，時間に曖昧性を持った概念で 時間情報を捉えなければならない．角本ほか(2004) はそのような曖昧性については図-2に示すような 概念で捉えている。本研究では, そこまで内容を複 雑にせず，それぞれの4つの時間について，行政資

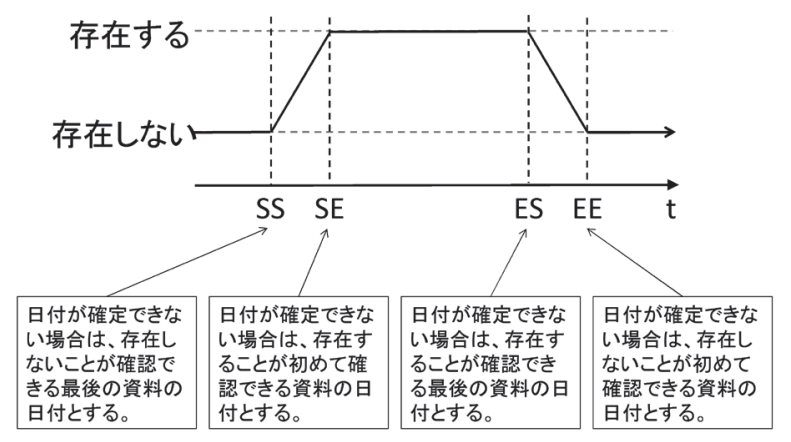

図 -1 発生消滅型地物の時間情報の考え方 (畑山ほか 1999 を改变)

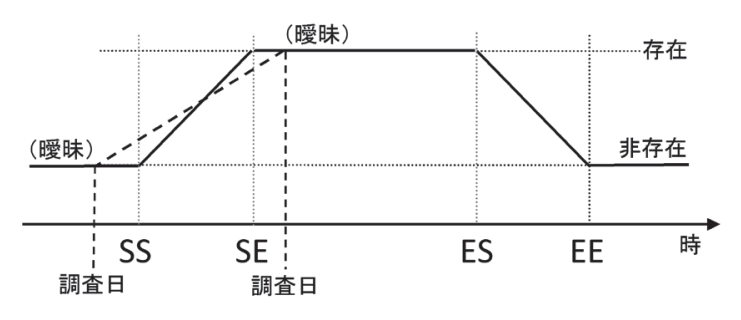
$\mathrm{SS}:$ 生成開始
$\mathrm{ES}:$ 生成開始
$\mathrm{SE}$ : 生成完了
$\mathrm{EE}$ : 生成完了

図 -2 時間情報の曖昧性を考慮した発生消滅型地物の 時間情報の考え方（角本ほか, 2004）
料に基づく厳密な時間情報なのか, 画像等の資料に 基づく曖昧性を持った時間情報なのかを，後で検証 できるように属性を付与することで対応した．

現実的には，SEやESについては厳密な日付を 入力することが可能な場合が多いと考えられるが, SS と EEについては困難な場合が多いと想定される. また, SSとEEについて曖昧さを許容しても入力が 不可能な場合には，それぞれSEと ESの日付を入れ ることになる。このように，時間に対して曖昧な運 用を許すことで，デー夕整備者の過剩な負担を減ら すことができ，実効的な時間情報の収集が可能とな る。地図表現上は, SS と SEの間の時間の地物は, 建設中の道路 (鉄道, 建物) という扱いになる。一 方 ESとEEの間の時間の地物については, 現在の地 形図等では表現されていないが, 廃線跡や解体中の 建物などとして扱われると考えられる。いずれにし ても，時間属性に応じてどのような地図表現をする かは地図作成者が自在に設定できることを想定して いる。

以上の検討結果から, 発生消滅型地物の時空間 データ仕様については, 地物毎に 4 つの時間属性を 入力することとし, 固定長のデータ仕様とした. 一 例として, 道路の場合の属性テーブルのテータ構造 を，表-1に示す.

表 -1 道路の固定長型デー夕構造

\begin{tabular}{|c|c|c|c|c|c|c|c|c|c|}
\hline $\begin{array}{c}1=-\Rightarrow \\
10\end{array}$ & 道路䡃别 & 道路区分 & 道路幅員 & 道路の名赫 & 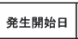 & 発生䅂了日 & 消娍朋姆安日 & 消減终了日 & 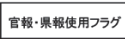 \\
\hline (8析) & (1桁) & (1桁) & (3析) & (text) & (8析) & (8析) & (8析) & (8析) & (1析) \\
\hline
\end{tabular}

（2）被覆型地物の時空間デー夕仕様

土地利用, DEMなどの被覆型地物に関しては, 筆者らは既存の研究とは独立して, 図-3で示すよ うな考え方の時間情報の付与を考えた，ある地点 （メッシュまたはポリゴン）において，実際に属性 Aが属性Bに変化した時刻をTtrue として, それを 示す近接の画像情報が $\mathrm{T} 1$ と $\mathrm{T} 2$ の場合, ここで確実 に言えるのは,「T1にはAが存在しており, Bは存 在していない」ことと,「T2にはAは存在しておらず, $\mathrm{B}$ が存在している」ことである。すなわち，Aは T1 から T2の間に消滅し, B は同期間に発生したこと 


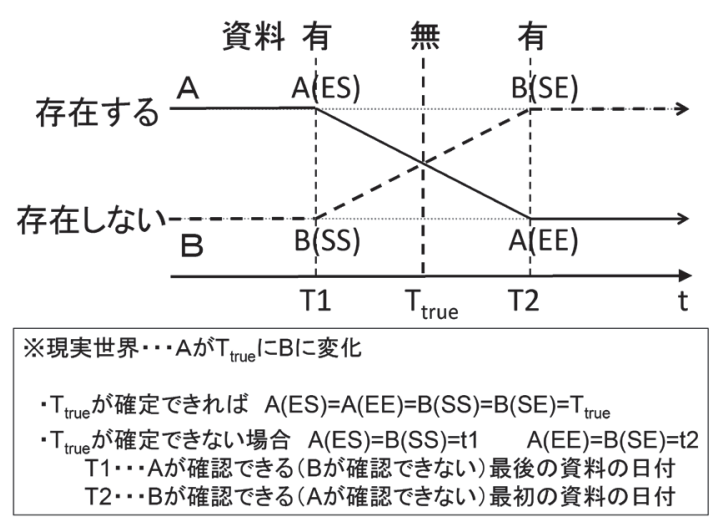

T1 T2の期間は、AまたはBが存在するあいまいな期間 (遷移期間)

図 -3 土地利用等の時間情報の考え方

になり, $\mathrm{T} 1$ は $\mathrm{A}$ の消滅開始 $(\mathrm{ES})$ 及び $\mathrm{B}$ の発生開始 ( $\mathrm{SS}), \mathrm{T} 2$ は $\mathrm{A}$ の消滅完了 $(\mathrm{EE})$ 及びB の発生完了 $(\mathrm{SE})$ となる。

以上の検討結果から, 被覆型地物の時空間デー夕 仕様については，属性が変化する毎にデー夕更新を 迅速に行えるように，更新属性情報と時間情報を メッシュまたはポリゴンごとに追加するような可変 長のデータ仕様とした，表-2に示すように，変化 が確認される毎に確認前後の 2 時期の画像の日付を 入力する, 土地の造成開始日のように, 変化の日付 が特定できる場合には, 同じ日付を 2 回入力すれば 良い。

表 -2 土地利用デー夕の可変長型データ構造

\begin{tabular}{|c|c|c|c|c|c|c|c|c|c|}
\hline $\begin{array}{c}\text { ב=-7 } \\
\text { ID }\end{array}$ & $\begin{array}{c}\text { 初年月日 } \\
\text { (西暦) }\end{array}$ & $\begin{array}{l}\text { 左記年 } \\
\text { の土地 } \\
\text { 利用 } \\
コ-F^{*}\end{array}$ & $\begin{array}{c}\text { 左記土地利用の } \\
\text { 消滅開始年月日 } \\
\text { (1回目変化の発 } \\
\text { 生開始年月日) } \\
\text { (西原) }\end{array}$ & $\begin{array}{l}\text { 左記土地利用 } \\
\text { の消滅完了年 } \\
\text { 月日(1回目変 } \\
\text { 化の発生完了 } \\
\text { 年月日)(西暦) }\end{array}$ & 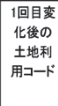 & $\sim$ & $\begin{array}{l}(n-1) \text { 回目変化 } \\
\text { の消嫁開始年 } \\
\text { 月日 ( } \mathrm{n} \text { 回目変 } \\
\text { 化の発生開始 } \\
\text { 年月日)(西暦) }\end{array}$ & $\begin{array}{c}\text { (n-1)回目変化の } \\
\text { 消淈完了年月日 } \\
\text { (n回目変化の発 } \\
\text { 生完了年月日) } \\
\text { (西厝) }\end{array}$ & 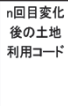 \\
\hline (8标) & 20000101 & (4标) & (8浙) & (8析) & (4妳) & $\sim$ & (8饰) & (8标) & (4杵) \\
\hline
\end{tabular}

\section{4. つくば市の時空間データセットの作成}

前述した時空間情報のデータ仕様の考え方に基づ き, 茨城県つくば市の一部において時空間デー夕 セットを構築した，空間範囲は，つくばエクスプレ ス（以下「TX」と略す）の開通により近年大規模土 地開発が急激に進んでいる, つくば市の研究学園駅 周辺の東西 $3 \mathrm{~km}$, 南北 $5 \mathrm{~km} の 15 \mathrm{~km}^{2}$ とした。時間範 囲は 2000 年以降の約 9 年間とした。衛星画像や資料 調査に基づいてほぼ 1 年以下の単位で地物の生成・ 消滅・変化を捉え, 時間精度の高い時空間デー夕を 作成した。データ項目は 2.5 万分 1 地形図に描画さ
れている主要項目として, 交通網, 土地利用 (メッ シュ，ポリゴン), DEM，建物，水系を採用した。

道路に関しては数值地図 5000 (土地利用) の道路 用地ポリゴンを使用し，ライン(中心線) 及びポリ ゴン（道路縁）を取得した。表-1のデータベースの 道路種別は，1.庭園路，2.石段，3.一般道，4.高速 道路, 5. その他とし, 道路区分は1. 国道, 2. 県道, 3.市 道, 4. その他の道路, 道路幅は真幅值とした。

土地利用については, 数值地図 5000 (土地利用) を基に 2000 年のメッシュデータとポリゴンデータ を作成し, その後の変化は空中写真や衛星画像等の 判読により差分を抽出する形で行った，表-2のデー タベースの土地利用コードは， 2.5 万分 1 地形図に 近い地図表現を行うため, 1. 広葉樹, 2. 針広混交林, 3. 針葉樹, 4. 竹林, 5. 荒地, 6. その他山林- 荒地等, 7. 田, 8. 畑, 9. 茶畑, 10. その他の樹木畑, 11. 造成中地 空地, 12.工業用地, 13. 住宅用地, 14. 商業業務用地, 15. 道路用地, 16. 公園・緑地等, 17. その他の公共 公益施設用地，18.河川・湖沼等，19. その他に区分 した

地形 (DEM) のデー夕仕様は, 表-2の土地利用コー ドを標高值に置き換えたものである。DEMは2001 年の北海道地図作成の $10 \mathrm{~m}$ メッシュ DEM（元データ は 2.5 万分 1 地形図)，2005年計測の航空レーザによ

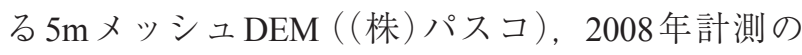
航空レーザによる $2 \mathrm{~m}$ メッシュ DEM (国際航業(株)) を使用した。 2001 年 DEM と 2005 年 DEMは $5 \mathrm{~m}$ 以上 の高さ変化のあった場合を，2005年DEMと 2008年 $\mathrm{DEM}$ は $2 \mathrm{~m}$ 以上の高さ変化のあった場合を変化箇所 とみなし，期間を通じて変化のないメッシュは2008 年の標高值を採用した。

建物データは，2005年オルソ画像の図化によっ て建物ポリゴンデータを作成し，1999年の空中写 真と 2000 年以降の衛星画像 (IKONOS, GeoEye-1 才 ルソ）を用いて 2005 年建物ポリゴンデー夕を 2000 年にさかのぼって修正し，その後時系列的に修正， 時間情報を付与した。

水系デー夕は, 数值地図 5000 (土地利用) から水 系を抽出し, 2000 年の水系デー夕（河川中心線, 水 涯線）を作成し，それ以降のオルソ画像と衛星画像 
（IKONOS, GeoEye-1オルソ）を用いて, 2000年のデー 夕を時系列的に修正，時間情報を付与した。

\section{5．時空間データセットによる地形図描画}

時空間データセットからある特定の時点(2000年, 2003 年，2006年，2009年の各4月1日）のデータを 抽出して描画した例を図-4に示す.

道路に関しては，道路縁デー夕をそのまま表示し た。幅員 $1.5 \mathrm{~m}$ 未満は徒歩道とし，破線表示とした。 庭園路は平成 14 年 2.5 万分 1 図式に従って表示した. また，時間属性により建設中の期間と判断される道
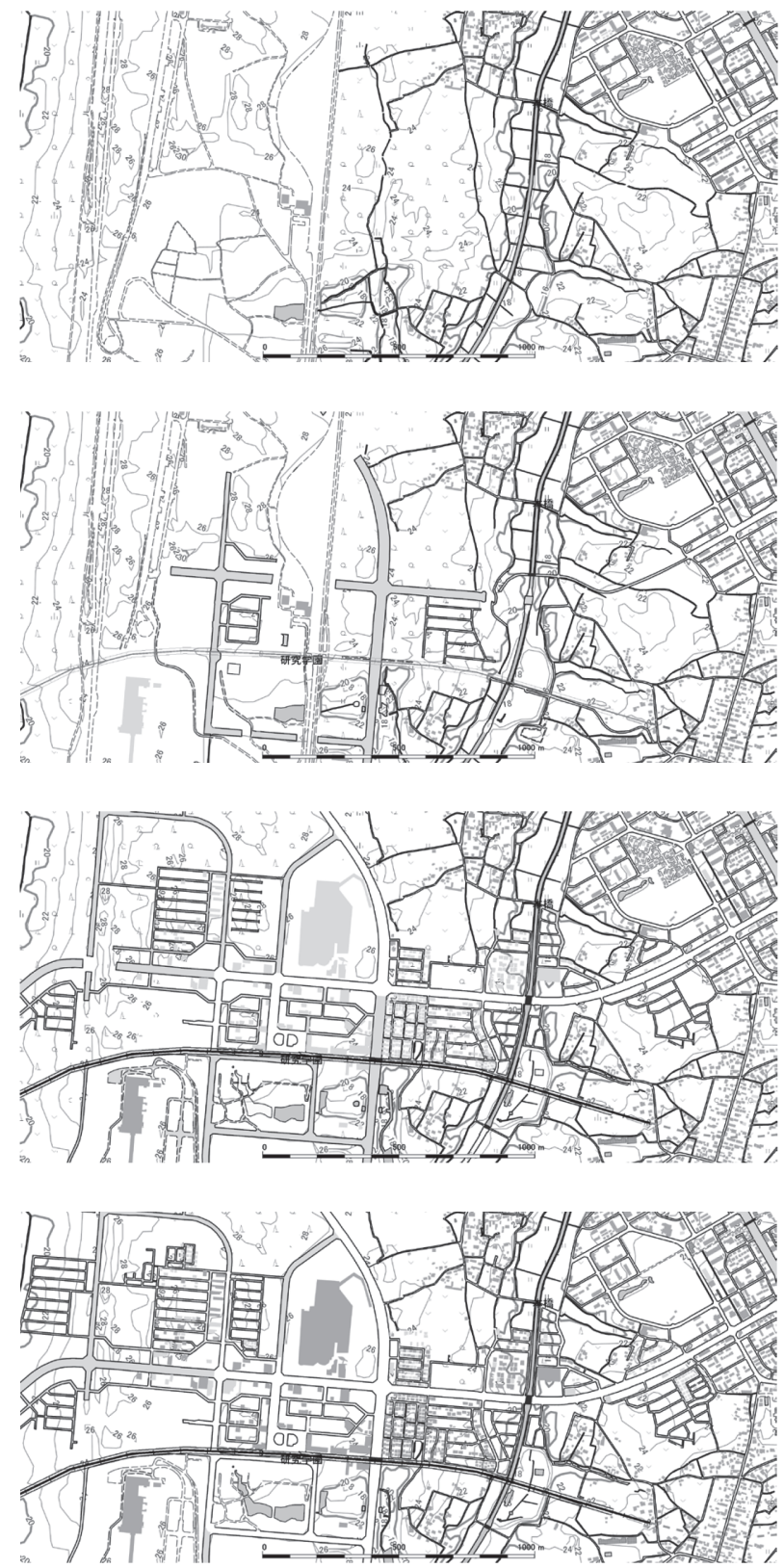

図 -4 時空間データセットの描画 （上から 2000 年, 2003 年, 2006 年, 2009 年)
路は，グレーで塗色した。土地利用に関しては，広 葉樹, 針広混交林, 針葉樹, 竹林, 荒地, 田, 畑, 茶畑，その他の樹木畑について，各テクスチャの読 み込みにより描画した。 DEM については, DEM か

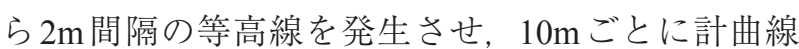
とした。ただし，等高線はすべて閉曲線として表示 するものとし, 岩がけ, 土がけ, 被覆等の表現は行っ ていない，建物はすべて真位置で描画し，総描等は 行わなかった。また，建設中期間の建物は通常建物 よりも色を薄く表示した，水系情報については，基 本的に 2.5 万分 1 地形図と同様の表現とした。なお, 幅が $5 \mathrm{~m}$ 未満の河川は河川中心線を一条河川として 表示した。限られたデー夕項目ではあるが，共通白 地図的なデータとして利用可能な描画表現ができて いるものと考える。

\section{6. つくば市時空間データを用いたデータ解析}

時空間地理情報を用いてデー夕解析を行うために は，時空間データセットから解析に必要な時間頻度 （例えば 1 年毎など）でデー夕を抽出して高頻度時系 列地理空間情報を作成し, 時系列解析を行えば良い。 本研究では，試作した時空間データを使用して 1 年 毎の時系列地理空間情報を作成し，TX沿線の土地 利用および建物の時間変化量の時空間解析を行っ た，TXの研究学園駅の位置を中心に，1000mまで $100 \mathrm{~m}$ 間隔で円バッファを発生させ，路線着工当時 からの各バッファにおける土地利用の変化量と変化 年を土地利用分類ごとに求め, 時間と土地利用変化 量の関係を考察した。

TX研究学園駅を中心とした面積集計結果のう ち，バッファ 300〜 400mを図-5に，900〜 1000mを 困-6に示す。なお，2006年と2007年は原資料がな く，変化情報を取得できなかったため，この結果で は2005〜2008年の3年間をまとめて表示している. いずれも2003年以降の変化面積が大きくなってい るが，これは TX開通（2005年10月）を間近に控え た開発ラッシュのためと思われる.

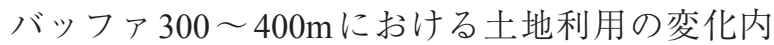
容については，2003～2004年は変化前が様々な土 地利用なのに対して, 変化後は造成中地が大部分を 


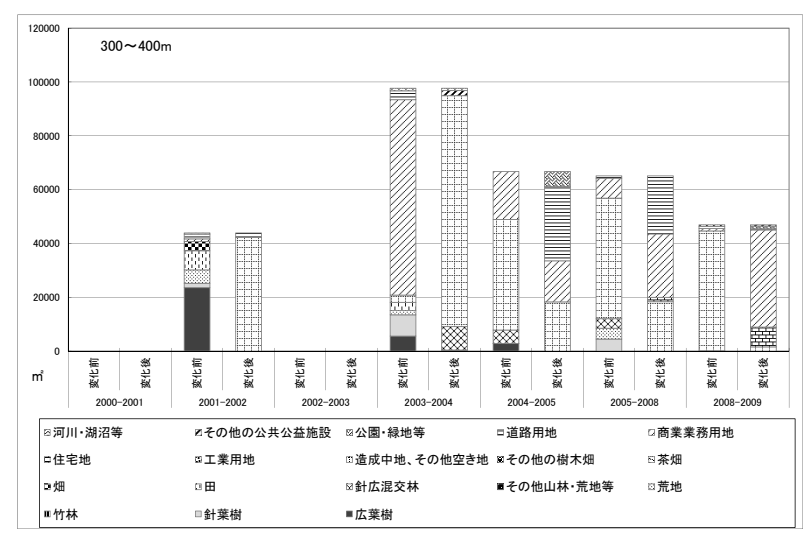

図 -5 TX 研究学園駅からバッファ 300-400m の土地 利用変化

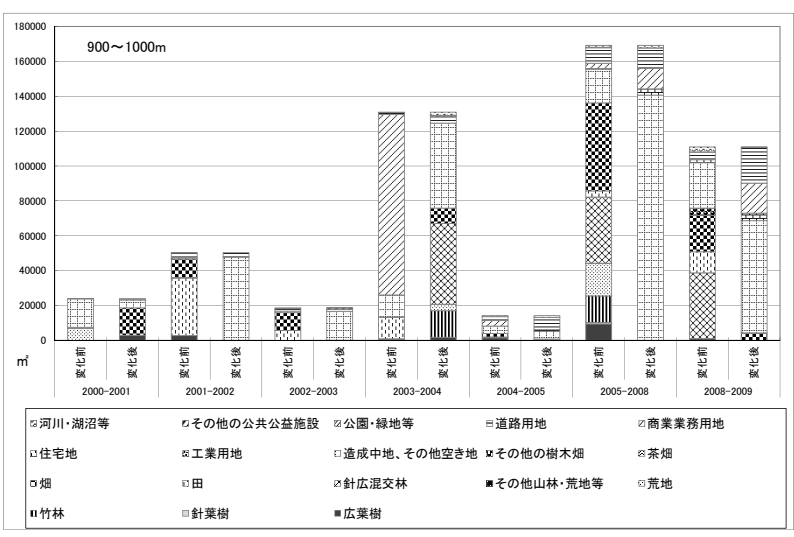

図 -6 TX 研究学園駅からバッファ 900-1000m の土地 利用変化

占めている，2008～2009年は，変化前は造成中地 が多いのに対し, 変化後は住宅用地, 商業業務用地 の割合が多く，開発が進んできている様子が伺え る.一方，バッファ $900 〜 1000 \mathrm{~m}$ に関しては，2008 年以降の変化量が大きく，バッファ300～400mよ りは開発が少し遅れている様子が伺われる。2008 〜2009年の変化は, 変化後の土地利用が造成中地 になっている割合が，バッファ 300〜 400mより大 きいことからも，その傾向が読み取れる。

以上のことから, 時空間データセットの更新が適 宜行われていれば, データセットから特定の時点の GISデータを切り出して時系列解析を行うことで, 国土計画や環境計画分野で有効な地理情報解析が行 える可能性があることを示すことができたと考え る.

\section{7. まとめ}

中縮尺レベルの基本図を対象に，時空間化すべき 地理空間情報の項目と仕様を検討し, 発生消滅型地 物と被覆型地物とに分けて, データ仕様を提示した。 提示したモデルでつくば市の TX沿線で時空間デー タセットを試作し，データセットから特定の時点の GIS データを抽出して, 共通白地図として活用可能 な描画や, 人為インパクトと土地利用変化との関連 性解析が可能であることを示した。

\section{謝辞}

本研究を進めるにあたり，以下の方々（敬称略） に御教示頂いた。 また, 若名の査読者からのコメン トが論文の改善に役立った。ここに記して心より感 謝申し上げる。村山祐司・堤盛人 (筑波大学)，角 本繁 (東京工業大学), 畑山満則 (京都大学), 吉川 耕司 (大阪産業大学), 浅野耕一 (秋田県立大学), 大澤裕 (埼玉大学), 清水英範・布施孝志 (東京大学), 井上亮 (東北大学), 浅野和仁 (富田林市), 太田守 重 (国際航業 (株)).

\section{参考文献}

明野和彦 ·星野秀和 ·安藤暁史 (2002) 旧版地形図 を利用した時空間データセットの試作「国土地理 院時報」，99，89-102.

角本繁・畑山満則 ·岡田憲夫 (2004) 時空間 GIS に よる地域情報共有と震災シミュレーション一緊急業 務にも対応できる平常時システムの実現一。京都 大学防災研究所年報」，47B，69-80.

門脇利広 · 中南清晃 · 小荒井衛 (2001) GIS 基盤情 報（数值地図 2500）の時系列管理手法に関する研究. $\lceil$ GIS- 理論と応用」，9(2)，61-66.

KIWI検討委員会 (1998)『KIWI Format Ver.1.10』, KIWI検討委員会編.

関本義秀・柴崎亮介 (2000) データベースのダイナ ミックな更新を目指した概念データモデルの提案. $\lceil$ GIS- 理論と応用」, 8(1)，63-73.

野中秀樹・大沢裕 (2001) トポロジー暗示型データ モデルをベースとする GISにおける処理時間に関す る実験的考察.「GIS-理論と応用」，9(2)，17-24. 
畑山満則・松野文俊 - 角本繁 - 龟田弘行 (1999) 時 空間地理情報システム DiMSIS の開発.「GIS- 理論と 応用」, 7(2), 25-33.

Cameron, S. (1990) Collision Detection by Four-Dimensional Intersection Testing. IEEE Transaction on Robotics and Automation, 6(3), 291-302.

Kumar, A., Tsotras, V.J. and Faloutsos, C. (1989) Designing access method for bitemporal database. IEEE Trans. on $K E, \mathbf{1 0}(1), 1-20$.

Raafat, H., Yang, Z. and Gauthier, D. (1994) Relational Spatial Topologies for Historical Geographical Information. International Journal of Geographical Information Systems, 8(2), 163-173.

Snodgrass, R. (1997) The temporal query language TQuel. ACM Trans. Database Systems, 12(2), 422-432.

Worboys, M. (1994) A Unified Model for Spatial and Temporal Information. The Computer Journal, 37(1), 2634.

（2010年10月6日原稿受理, 2012年11月19日採用決定, 2013 年 4 月 26 日デジタルライブラリ掲載) 